\title{
Erratum: Ochronotic Spondyloarthropathy Mimicking Diffuse Idiopathic Skeletal Hyperostosis
}

Sadettin Uslu, M.D.

Department of Rheumatology, Ömer Halisdemir University Bor Physical Medicine and Rehabilitation, Training and Research Hospital, Niğde, Turkey

J Rheum Dis 2020;27:213-214

https://doi.org/10.4078/jrd.2020.27.3.213

In the published article "Ochronotic Spondyloarthropathy Mimicking Diffuse İdiopathic Skeletal Hyperostosis. J Rheum Dis 2020;27(3):213-214. https://doi.org/10.4078/jrd.2020.27.3.213", the title was given incorrectly. In the title of this article, the word "Idiopathic" should be corrected "Idiopathic". The author apologizes for any inconvenience that it may have caused.

The title should be corrected as follows:

Ochronotic Spondyloarthropathy Mimicking Diffuse Idiopathic Skeletal Hyperostosis

Corresponding to : Sadettin Uslu (iD http://orcid.org/0000-0001-6266-2454

Department of Rheumatology, Ömer Halisdemir University Bor Physical Medicine and Rehabilitation, Training and Research Hospital, Dr. Doğan Baran Avenue on Okçu Road 1.km Bor, Niğde 51200, Turkey. E-mail : sadouslu@gmail.com

Copyright (c) 2020 by The Korean College of Rheumatology.

This is an Open Access article, which permits unrestricted non-commerical use, distribution, and reproduction in any medium, provided the original work is properly cited. 